\title{
Penelitian perancangan sarana bantu belajar bahasa untuk anak tunarungu dengan pendekatan participatory design
}

\author{
Devanny Gumulya ${ }^{1 *}$, Florencia $\mathrm{Ho}^{1}$ \\ ${ }^{1}$ Program Studi Desain Produk, Universitas Pelita Harapan, Tangerang, Indonesia
}

\begin{abstract}
This research focused on deaf students in the third year of junior high school. When communicating in writing the structure of the grammar of deaf students is often reversed, ironically, they're expected to pass on national test for normal students. This study uses a participatory design approach because all stakeholders involved in the design process are considered as coworkers in decision making. The designer, teacher and student are the stakeholders involved in this research. The group discussion forum was conducted to understand the types of games that are easy but fun to play for deaf students and to get feedback and recommendations for improvements from the games that have been made. This study produced language learning aids in the form of educational grammar games for third-year deaf students of junior high school. The theme of the grammar game that was appointed was adapted to the practical lessons at Yayasan Karya Dharma Wanita (YKDW), namely cooking and salons. The results of the study were tested in another deaf school which is Pangudi Luhur and the results were obtained that the product could be well received, even though they have different educational approach from YDKW. This study finally concluded that in Indonesia there isn't standardization regarding the deaf kid's education system.
\end{abstract}

Key words: product design, language learning tools, deafness

\begin{abstract}
Abstrak
Penelitian ini difokuskan pada siswi tunarungu tingkat SMP tahun ke tiga. Ketika berkomunikasi secara tertulis struktur tata bahasa siswi tunarungu sering terbalik - balik, ironisnya siswi Tunarungu akan mengikuti ujian akhir nasional siswa normal. Di sisi lain, anak tunarungu memiliki kemampuan praktik yang cukup baik. Penelitian ini menggunakan pendekatan participatory design yang bersifat demokratis di mana semua stakeholder yang terlibat dalam proses desain dianggap sebagai rekan kerja dalam pengambilan keputusan. Perancang, guru dan siswi adalah stakeholder yang terlibat dalam penelitian ini. Forum group discussion dilakukan untuk memahami tipe permainan yang mudah tapi seru untuk dimainkan siswi tunarungu serta untuk mendapatkan feedback dan rekomendasi perbaikan dari permainan yang sudah dibuat. Penelitian ini menghasilkan sarana bantu belajar bahasa berupa permainan edukatif tata bahasa untuk siswi tunarungu siswi SMP tahun ketiga. Tema permainan tata bahasa yang diangkat disesuaikan dengan pelajaran praktik di YKDW, yaitu tata boga dan salon. Hasil penelitian diujicoba ke Sekolah Luar Biasa Pangudi Luhur dan diperoleh hasil bahwa produk tersebut dapat diterima dengan baik, walaupun pendekatan pendidikan mereka berbeda dengan YDKW. Penelitian ini akhirnya menyimpulkan bahwa di Indonesia belum ada standar yang terukur dalam pendidikan siswi tunarungu.
\end{abstract}

Kata kunci: desain produk, sarana belajar bahasa, tunarungu

\section{Pendahuluan}

Bahasa merupakan sarana perantara komunikasi seseorang, sarana untuk menyampaikan informasi kepada orang lain secara lisan maupun tulisan agar orang dapat mengerti maksud dan tujuan yang kita inginkan. Dalam hubungan bermasyarakat, bahasa berfungsi sebagai alat untuk bekerja sama serta sebagai alat untu mengekspresikan diri. Oleh karena itu, keterampilan dalam berbahasa seperti keterampilan membeo, berbicara, membaca dan menulis sangat penting dan saling berkaitan satu sama lain. Naluri untuk berbahasa dimulai sejak dari bayi. Ketika sang bayi berusaha mengeluarkan suara sebagai interaksinya terhadap apa yang didengar dari lingkungan sekitarnya.

Anak tunarungu memiliki kekurangan pada indera pendengaran. Hilangnya fungsi pendengaran

\footnotetext{
* Corresponding author Tel : +62-888-8564-165 ; e-mail : devanny.gumulya@uph.edu
} 
mengakibatkan anak mengalami hambatan dalam menerima informasi sehingga berdampak pada kemampuan lisan dan tulisan (Sadjaah, 2005), sehingga proses untuk belajar bahasa sangat lambat karena mereka hanya dapat memahami lawan bicara mereka dengan cara membaca gerakan bibir yang pelan. Hambatan dalam perkembangan bahasa yang dialami oleh anak tunarungu adalah kemampuan mereka dalam a) menyusun urutan kata, b) penggunaan fungsi kata, c) penggunaan awalan dan akhiran kata, d) menyusun gabungan kata menjadi sebuah kalimat, e) bentuk kalimat, f) struktur kalimat.

Pada umumnya perkembangan bahasa anak tunarungu dimulai dari pengalaman atau situasi antara bayi dan ibu atau orang lain dalam lingkungan terdekatnya, melalui pengalaman tersebut, anak "belajar" menghubungkan pengalaman dan simbol ekspresi tangan dan gestur tubuh. Tunarungu secara bertahap belajar menggunakan bahasa isyarat. Peranan bahasa, kemampuan bicara dan indera pendengaran dalam konteks komunikasi merupakan hal yang saling berkaitan. Terganggunya indera pendengaran sangat berpengaruh terhadap penerimaan bahasa dalam bentuk suara. Maka dalam proses penerimaan bahasa anak tunarungu lebih mengedepankan fungsi indera visual.

Sekolah Luar Biasa (SLB) atau Sekolah Khusus (SKh) adalah sarana pendidikan yang dibentuk agar anak-anak yang memiliki kebutuhan khusus dapat mengayomi pendidikan yang sama dengan anak pada umumnya. Metode pendidikan yang diajarkan disesuaikan dengan kebutuhan, kemampuan dan potensi yang dimiliki oleh individu. Penyandang tunarungu dikategorikan dalam SLB-B dan lebih berkomunikasi secara verbal dan non-verbal yaitu dengan media tulisan dan menggunakan gerakan tubuh, gerakan mulut atau mimik wajah yang biasa dikenal dengan bahasa isyarat. Proses pengenalan bahasa isyarat atau SIBI, pembelajaran bahasa, hingga terapi wicara sudah diajarkan, namun perkembangan setiap anak berbeda tergantung dengan sisa pendengaran yang mereka miliki dan keinginannya untuk belajar. Metode pengulangan terhadap materi merupakan metode yang digunakan dengan tujuan penyandang tunarungu bisa dan memahami materi yang sedang diajarkan.

Yayasan Karya Dharma Wanita (SKh YKDW) merupakan sekolah anak luar biasa (SLB) yang dipimpin oleh $\mathrm{Hj}$. Chandra Elia Ismet Iskandar sebagai Ketua Yayasan Karya Dharma Wanita. Sekolah ini terletak di Jl. Teuku Umar No.76 Nusa Jaya Karawaci Kota Tangerang. SKh YKDW sendiri terbagi menjadi 3 sekolah, yaitu YKDW 01 untuk penyandang autism, YKDW 02 untuk penyandang tunarungu dan tunanetra, dan YKDW 03 untuk penyandang disabilitas. Di YKDW ada jenjang TK SMA.

Di Indonesia, sarana belajar khusus tunarungu yang tersedia secara umum adalah alat peraga dan buku kamus bahasa isyarat. Siswa tunarungu diwajibkan untuk menghafal bahasa isyarat alphabet dan katakata seperti mau, cantik, dll. Namun bila dilihat perkembangannya juga minim, belum ada inovasi khusus yang mempermudah proses belajar siswa tunarungu.

Di sisi lain, desain produk adalah keilmuan yang berhubungan pemecahan masalah secara kreatif dan memiliki kemampuan untuk membantu anak tunarungu belajar bahasa. Karena anak tunarungu belajar dengan mengutamakan indra penglihatan, dan desain adalah ilmu visual dan berhubungan dengan kreativitias.

\section{Bahan dan metode}

Tunarungu memiliki kemampuan mendengar yang berbeda dengan kebanyakan orang, oleh karena itu kemampuan mendengar anak penyandang tunarungu dikelompokkan seperti yang ditunjukkan oleh Tabel 1. Karena ketidakmampuannya mendengar, maka dalam berkomunikasi anak tunarungu menggunakan bahasa isyarat. Bahasa Isyarat Indonesia (BISINDO) adalah salah satu bahasa isyarat yang berlaku di Indonesia. Ada dua bahasa isyarat yang digunakan di Indonesia, yaitu Sistem Bahasa Isyarat Indonesia atau SIBI dan Bahasa Isyarat Indonesia atau BISINDO. Perbedaan mendasar antara SIBI dan BISINDO adalah SIBI menggunakan abjad sebagai panduan bahasa isyarat tangan satu, sementara BISINDO menggunakan gerakan tangan (dua tangan) sebagai upaya komunikasi antar pengguna bahasa isyarat.

BISINDO merupakan bahasa isyarat alami budaya asli Indonesia yang dengan mudah dapat digunakan dalam pergaulan isyarat kaum tunarungu sehari-hari. Bisindo merupakan bahasa ibu mereka. Setiap penyandang tuli pun memiliki bahasa ibu yang otentik, serupa dengan bahasa daerah yang berkembang di setiap wilayah Indonesia. Sebuah riset menemukan bahwa bahasa isyarat yang berlaku di Jakarta dan Yogyakarta memiliki keterkaitan tetapi ada perbedaan (Isma, 2012). Riset itu melaporkan bahwa diperkirakan $65 \%$ bahasa isyarat di kedua kota tersebut memiliki persamaan dalam arti namun secara tata bahasa berbeda (Gambar 1).

Metode komunikasi penderita tunarungu lainnya adalah Metode Maternal Reflektif (MMR). Metode Maternal Reflektif atau Metode Percakapan 
Reflektif adalah metode komunikasi yang sering digunakan ibu sewaktu berbicara dengan bayi yang belum memiliki bahasa. Metode Maternal Reflektif dapat disingkat MMR. Proses dari MMR adalah sang ibu berbicara kepada bayinya yang belum bisa berbahasa secara berulang-ulang, bayinya berusaha meniru bicara ibunya. Sang ibu terus dengan konsisten berbicara, misalnya, "saya mama". Bayinya akan berusaha meniru suara ibunya sedikit demi sedikit seiring pertumbuhannya. "ma... ma..." Akhirnya bayi dapat berbicara. Itulah semua adalah cara MMR. Karena metode ini sangat naluriah dan bersifat intuisi maka metode ini dapat dijadikan pijakan bagi anak-anak tunarungu untuk belajar berbahasa, berbicara, dan membaca ujaran.

\section{Proses komunikasi}

Penyandang tunarungu pada dasarnya tidak berbeda dengan individu pada umumnya, akan tetapi ada beberapa hal yang perlu dikhususkan pada saat berkomunikasi dengan penyandang tunarungu, seperti: (1) berbicara harus berhadapan; (2) bicara dengan jelas, tidak dibuat-buat; (3) mulut tidak tertutup benda apapun ketika bicara; (4) bicara jangan terlalu cepat atau lambat; dan (5) bila menggunakan isyarat, lakukanlah dengan jelas. Gambar 2 menunjukkan proses komunikasi pada anak tunarungu.

Tabel 1. Pengelompokan klasifikasi pendengaran

\begin{tabular}{ll}
\hline \multicolumn{1}{c}{$\begin{array}{c}\text { Kelompok } \\
\text { Klasifikasi }\end{array}$} & \multicolumn{1}{c}{ Penjelasan } \\
\hline $\begin{array}{l}\text { Tunarungu } \\
\text { sangat ringan } \\
(27-40 \mathrm{~dB})\end{array}$ & $\begin{array}{l}\text { Menunjukkan kesulitan mendengar bunyi yang } \\
\text { jauh, memerlukan terapi wicara. Dalam proses } \\
\text { belajar masih memungkinkan untuk } \\
\text { menempatkan anak di tempat strategis }\end{array}$ \\
$\begin{array}{l}\text { Tergolong } \\
\text { tunarungu }\end{array}$ & $\begin{array}{l}\text { Mengerti bahasa percakapan jarang 3 kaki \& } \\
\text { berhadap-hadapan }\end{array}$
\end{tabular}
ringan $41-55$ $\mathrm{dB}$

$56-70 \mathrm{~dB}$

Tergolong tunarungu agak berat. Hanya bisa mendengar suara dari jarak yang dekat, masih memiliki sisa pendengaran untuk belajar bahasa dan menggunakan alat bantu dengar dengan cara yang khusus.

$71-90 \mathrm{~dB}$

Tergolong tunarungu berat, sudah tergolong tuli. Dapat belajar berkomunikasi dengan teknik-teknik khusus.

$>90 \mathrm{~dB} \quad$ Tergolong tunarungu parah/extreme/tuli. Cenderung mengenali suara melalui getaran.

Sumber: Klasifikasi Anak Tunarungu (BisaMandiri, 2015)
Pengirim pesan yang dimaksud pada Gambar 2 tersebut adalah orang yang mempunyai ide untuk menyampaikan pesan dan berharap orang lain dapat menerima pesan sesuai dengan apa yang ia maksud. Materi pesan dapat berupa informasi, ajakan, pernyataan, rencana, dan lainnya. Simbol atau isyarat pada Gambar 2, menerangkan bahwa pada tahap ini, pengirim pesan membuat kode atau simbol sehingga pesannya dapat dipahami oleh orang lain. Biasanya dalam bentuk kata-kata atau gerakan tubuh. Media penghubung yang dimaksud adalah sarana untuk menyampaikan pesan. Contohnya bahasa isyarat, media tulis, sosial media, atau media lainnya yang dapat menyampaikan pesan. Mengartikan kode/isyarat merupakan suatu tahap di mana pesan yang telah diterima, diterjemahkan ke dalam pemahaman penyandang tunarungu. Penerimaan pesan merupakan proses penerimaaan pesan dan proses persetujuan atau tidak dengan pengirim pesan. Sedangkan respon merupakan tahap di mana penerima pesan memberikan atau membalas respon kepada sang pengirim pesan.

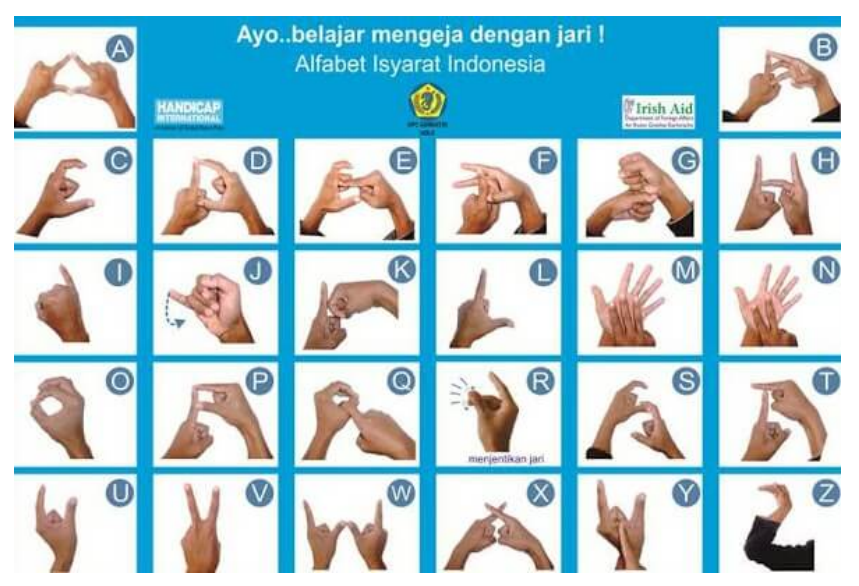

Gambar 1. Alftabet BISINDO

Sumber : bisamandiri.com

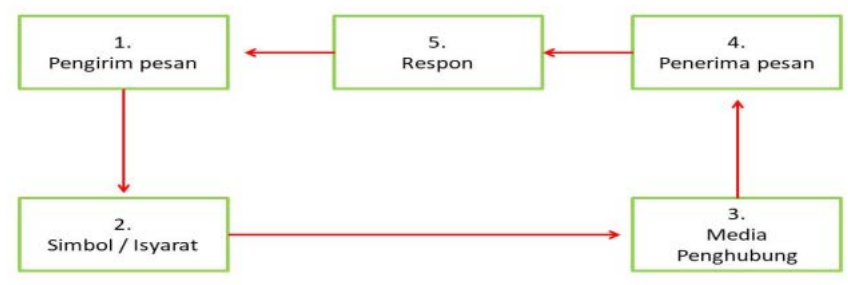

Gambar 2. Proses komunikasi pada anak tunarungu Sumber: Pembelajaran adaptif bagi anak berkebutuhan khusus (Melinda, 2013) 


\section{Teori partisipasi}

Menurut Institut Studi Pengembangan dari Universitas Sussex di Inggris yang fokus meneliti perkembangan metode partisipasi: rangkaian aktivitas yang memampukan orang biasa berperan aktif dan mengambil posisi sebagai pengambil keputusan yang mempengaruhi kehidupan mereka secara langsung. Artinya dengan metode ini, kepentingan orang harus disimak dan dipertimbangkan menjadi usulan solusi. Metode ini sudah digunakan oleh banyak peneliti, komunitas, serta organisasi sosial, karena sifat dari metode ini yang sangat menghargai kepentingan lokal, output dari metode ini adalah intervensi yang merefleksikan realitas lokal, akhirnya hasil lebih didukung dari berbagai pihak dan menghasilkan perubahan sosial yang signifikan.

Metode ini sudah digunakan di banyak konteks perkotaan dan pedesaan, miskin dan kaya, dan mancanegara. Metode ini dapat diterapkan dalam seluruh proses aktivitas mulai dari pengambilan data, analisa, pengambilan keputusan. Sekilas sejarah, metode ini sudah mulai dikembangkan sejak tahun 1970an dipelopori oleh Robert Chambers salah satu peneliti dari Universitas Sussex. Ia sudah menyebarkan metode ini ke Asia Tenggara, Afrika dan Eropa. Metode partisipasi ini semakin besar pengaruhnya karena dianggap sebagai pendekatan alternatif dari perkembangan yang top-down dan pergerakan yang bersifat linear.

Ada 6 prinsip utama dalam metode partisipasi. Yang pertama adalah semua orang berhak berpartisipasi. Pihak - pihak yang akan terpengaruh oleh keputusan - keputusan harus diikutsertakan dalam proses, khususnya pihak minoritas. Yang kedua adalah mendengarkan suara yang tidak terdengar. Metode ini memungkinkan peneliti untuk mendengar hal - hal yang tidak terlihat di observasi. Semua pihak bebas mengutarakan kekhawatirannya. Yang ketiga adalah kearifan dan keberagaman lokal menjadi titik awalnya Orang lokal memiliki pengetahuannya tentang komunitasnya, walaupun masing - masing pasti mempunyai perspektif, pengalaman, serta interpretasi yang berbeda. Yang keempat adalah meninggalkan pola berpikir yang lama. Prekonsepsi yang lama ditinggalkan untuk mendapatkan hal - hal yang baru komunitas. Hal ini berarti siap untuk melupakan apa yang sudah dipelajari sebelumnya. Yang kelima adalah penggunaan multi metode. Berbagai metode digunakan demi mendapatkan pembelajaran dan analisa yang sesering mungkin. Dan yang keenam adalah perubahan sikap dan perilaku. Kedua hal ini sangatlah vital bagi metode partisipasi.

Menurut Baker, dkk., karakteristik dari pendekatan partisipasi adalah (1) penyebaran pengetahuan dan informasi; (2) perbedaan sudut pandang diakui dan didengarkan; (3) bekerja dalam kelompok untuk kegiatan yang bersifat praktek; (4) terjadi proses pembelajaran yang bersifat kreatif dan terbuka untuk pengembangan secara kontinu; (5) adanya kesepakatan pemahaman secara kolektif dan ada rasa kepemilikan bersama atas output yang dihasilkan; dan (6) kapasitas untuk refleksi dan penilaian diri sendiri (Baker, Dearden, \& Thomas, 2003).

Metode partisipasi dapat melahirkan inovasi sosial bila terjadi peningkatan pada beberapa indicator (Katoppo, 2018), yaitu; (1) tingkat pemahaman dan keterlibatan target sepanjang pengembangan intervensi; (2) tingkat kreativitas dan inovasi baru yang ditunjukkan target sepanjang proses perencanaan, pelaksanaan dan pemeliharaan; dan (3) tingkat keterbukaan terhadap evaluasi, kemungkinan keberlanjutan dan replikasi fleksibel program di tempat asal dan penularan di tempat lain.

Perancangan didekatkan dengan teori partisipasi karena sifat dari teori ini yang demokratis dan saling hormat. Kedua hal ini sangat dibutuhkan bila ingin menghasilkan sarana belajar yang tepat dan berguna bagi Skh YKDW 02. Tahapan proses metode partisipasi menurut (Involve, 2005), yaitu pemetaan kondisi awal, pemetaan informasi yang tersedia, pembinaan relasi antar semua stakeholder yang terlibat, penetapan visi yang mau dicapai bersama, penggalian ide, rekomendasi, dan peningkatan kapasitas peserta.

\section{Participatory Action Research}

PAR (Participatory Action Research) adalah pelaksanaan penelitian untuk mendefinisikan sebuah masalah dan menerapkan informasi yang diperoleh ke dalam aksi sebagai solusi atas masalah yang telah terdefinisi (Afandi, 2013). PAR adalah "penelitian oleh, dengan, dan untuk orang”. PAR bersifat partisipatif. Dalam proses penelitian Participatory Action Research, diperlukan kondisi di mana orang turut berperan di dalam penelitian dan memiliki informasi yang relevan tentang sistem sosial (komunitas) yang berada di dalam lingkup pengkajian, dan di dalam rancangan serta implementasi dari aksi dilakukan berdasarkan hasil penelitian.

PAR adalah pengalaman dan pembelajaran hasil dari pekerjaan sekelompok orang, dan pembelajarannya dapat diakses orang lain (Katoppo, 2018; McTaggart, 1994). Oleh karenanya PAR bukan hanya tentang pembelajaran, tetapi juga tentang produksi pengetahuan (knowledge production) dan perbaikan dalam praksis (improvement of practice) dalam sebuah kelompok sosial yang komit. PAR 
sendiri selalu berusaha untuk mencapai tujuan posisi ideal, yaitu mencari cara berpraktik yang berlandaskan teori setara (theoretically informed practice). Ernest Stringer kemudian memberikan tahapan pelaksanaan PAR: Look (Melihat) - Think (Berpikir) - Act (Bertindak) (Stringer, 2013). Menurut John Elliott, karena pendekatan metode ini bersifat demokratis dengan output yang berorientasi pada pengembangan kapasitas, maka metode ini sering digunakan untuk mendorong kegiatan yang memiliki output inovasi sosial (Elliot, 1991).

Salah satu penelitian perancangan dengan pendekatan metode partisipatory action research di tahun 2013 - 2014 dilakukan oleh Chen-Fu Yang \& Tung-Jung Sung yang mengangkat topik perancangan desain servis untuk pencegahan dan screening kanker, untuk restoran, pertanian berkonsep berkelanjutan, serta servis edukasi untuk anak - anak dan remaja oleh 5\% Design Action, NGO di Taiwan. Dari keempat proyek ini dihasilkan kesimpulan bahwa pendekatan partisipasi dapat menghasilkan output yang memiliki karakter (1) Multi-method, yaitu mengakui keragaman 'suara' atau bahasa yang digunakan oleh setiap stakeholder yang terlibat; (2) Reflexive, yaitu mengikutsertakan NGO, desainer, public dan swasta dalam merefleksikan makna dan menanggapi interpretasi atas data; dan (3) Adaptable, yaitu dapat diaplikasikan pada berbagai konteks penempatan (Yang \& Sung, 2016).

Dalam melakukan riset ini, peneliti menggunakan metode pendekatan partisipasi, dengan tujuan agar perancang dapat lebih berempati dan mendengarkan kebutuhan siswi. Beberapa variabel yang dilihat dari penelitian perancangan ini, sesuai dengan pandangan Katoppo bahwa metode partisipasi dapat melahirkan inovasi sosial bila ada indikasi peningkatan dalam hal (1) tingkat pemahaman dan keterlibatan target sepanjang pengembangan intervensi; (2) tingkat kreativitas dan inovasi baru yang ditunjukkan target sepanjang proses perencanaan, pelaksanaan dan pemeliharaan; (3) tingkat keterbukaan terhadap evaluasi, kemungkinan keberlanjutan dan replikasi fleksibel program di tempat asal dan penularan di tempat lain (Katoppo, 2018).

Langkah awal penelitian yang dilakukan adalah mempelajari kurikulum pendidikan bahasa usia dasar YKDW. Kurikulum pendidikan ini dirancang berlangsung selama 6 tahun. Ini perlu dilakukan untuk memahami tingkatan pembelajaran bahasa yang ada di YKDW. Selain mempelajari kurikulum, sarana dan prasarana yang ada perlu diketahui buku, alat peraga, dll. Penelitian ini tidak menghasilkan metode belajar bahasa yang baru tapi mengadopsi yang sudah ada untuk kemudian dibuatkan sarana belajar yang lebih interaktif dan menyenangkan bagi anak tunarungu. Selain itu, pemahaman tentang tingkat klasifikasi tunarungu yang ada di YKDW dan kemampuan berbahasa masing - masing siswa juga harus dimiliki oleh peneliti.

Langkah berikutnya adalah menyelenggarakan FGD Partisipasi 1 dengan topik "Permainan apa yang kusuka". Peneliti membawa lima permainan yang dimainkan oleh peserta masing-masing selama 10 menit. Di akhir permainan peserta diminta untuk menjawab beberapa pertanyaan yang meliputi: (1) permainan apa yang sering dimainkan?; (2) apa yang membuat permainan tersebut disukai?; dan (3) apa yang membuat permaian tersebut tidak disukai?. Peserta juga diminta untuk menilai tingkat keseruan masing-masing permainan. Tingkat keseruan permainan tersebut diwujudkan dalam skor 1-5. Nilai (1) untuk tidak seru, (2) kurang seru, (3) biasa saja, (4) seru, (5) sangat seru, apa penilaian kalian terhadap permainan ini?

Dari hasil workshop partisipasi tersebut, peneliti dapat memahami kendala belajar bahasa dari perspektif anak tunarungu. Data ini digabungkan dengan hasil studi sarana belajar bahasa yang ada di sekolah untuk kemudian menjadi landasan dalam mendesain sarana belajar yang baru. Selanjutnya akan mengikuti proses desain secara umum mulai dari sketsa, gambar teknik. Desain terbaik kemudian dibuat modelnya dalam skala 1:1. Setelah model jadi dan diuji coba ke YKDW. Pada FGD Partisipasi 2, produk disimulasikan permainannya. Guru dan murid memberi tanggapan apa yang perlu disempurnakan dari model ini, sebelum produk difinalisasi.

\section{Hasil dan pembahasan}

Penelitian dimulai dengan proses memahami subjek penelitian yaitu siswi tingkat 3 SMP Skh YKDW. Wawancara dengan guru wali kelas dan dengan beberapa siswi tunarungu di kelas tersebut menghasilkan beberapa fakta berikut.

YKDW menerima semua anak tunarungu dengan tingkat IQ (Intelligence Quotient) yang beragam dari yang normal hingga kurang, hal ini berdampak pada kemampuan berkembang anak yang bergantung pada tingkat IQ yang dimiliki. Lima siswa memiliki IQ normal, dan dua memiliki IQ di bawah rata-rata. Proses pengenalan bahasa isyarat atau SIBI, pembelajaran bahasa, hingga terapi wicara sudah diajarkan sejak jenjang sekolah dasar, namun perkembangan setiap anak berbeda tergantung dengan 
sisa pendengaran yang mereka miliki dan keinginannya untuk belajar. Perkembangan kemampuan bahasa siswi tunarungu mengalami kendala sangat besar, karena tidak semua anak memiliki tingkat kecerdasan rata-rata.

Siswi dengan IQ normal dapat membaca dan menyalin tulisan per kata dari papan ke buku tulis, namun bila menulis kalimat sendiri, tata bahasanya sering terbalik-balik. Siswi dengan IQ normal dapat menceritakan kembali teori pendek yang telah dijelaskan oleh guru. Sedangkan siswi dengan IQ di bawah rata-rata dapat membaca teks pendek, tapi belum paham apa yang dibaca. Mereka sudah bisa menyalin tulisan per kata dari papan tulis ke buku. Metode pengulangan terhadap materi merupakan metode yang digunakan dengan tujuan penyandang tunarungu bisa dan memahami materi yang sedang diajarkan

Untuk kemampuan bicara, semua anak belum dapat mencapai kemampuan bicara yang jelas, karena tidak ada konsistensi dalam melakukan terapi bicara. Penyandang tunarungu umumnya lebih cepat menangkap pelajaran yang bersifat ilmu pasti, seperti matematika, ilmu pengetahuan alam, dan ilmu pengetahuan sosial karena angka bersifat konkret, ilmu pengetahuan alam dan sosial merupakan sesuatu yang dapat ditafsirkan dengan wujud pasti, terdapat dan terjadi di lingkungan hidup. Untuk pelajaran seperti bahasa Indonesia, bahasa Inggris dan agama sebenarnya mereka dapat mengerti namun perlu latihan dan penjelasan ekstra agar mereka dapat paham tentang hal tersebut. Oleh karena itu, anak penyandang tunarungu lebih dominan dalam bidang non-akademik seperti bermain, olahraga, menari, memasak dan keterampilan lainnya karena dengan melakukan suatu hal yang menyenangkan dengan mempraktekkan secara langsung dapat membantu dan melatih berbagai keahlian dan ilmu yang berbeda sehingga dapat mendukung proses perkembangan anak. Siswi tunarungu merasa lebih percaya diri pada pelajaran praktek seperti tata boga, salon, dan olah raga dari kelas yang bersifat teori.

Siswa tunarungu saling berkomunikasi dengan menggunakan bahasa isyarat atau media tulis. Mereka kesulitan ketika berkomunikasi dengan orang normal karena orang lain memerlukan waktu untuk menangkap pesan yang akan disampaikan. Hal itu disebabkan oleh tata bahasa yang mereka gunakan cenderung terbalik-balik. Gambar 3 menunjukkan kemampuan komunikasi yang dimiliki Atikah, salah satu koresponden penelitian. Berikut beberapa hasil percakapan melalui aplikasi Line dan screenshot caption halaman Instagram milik Atikah.

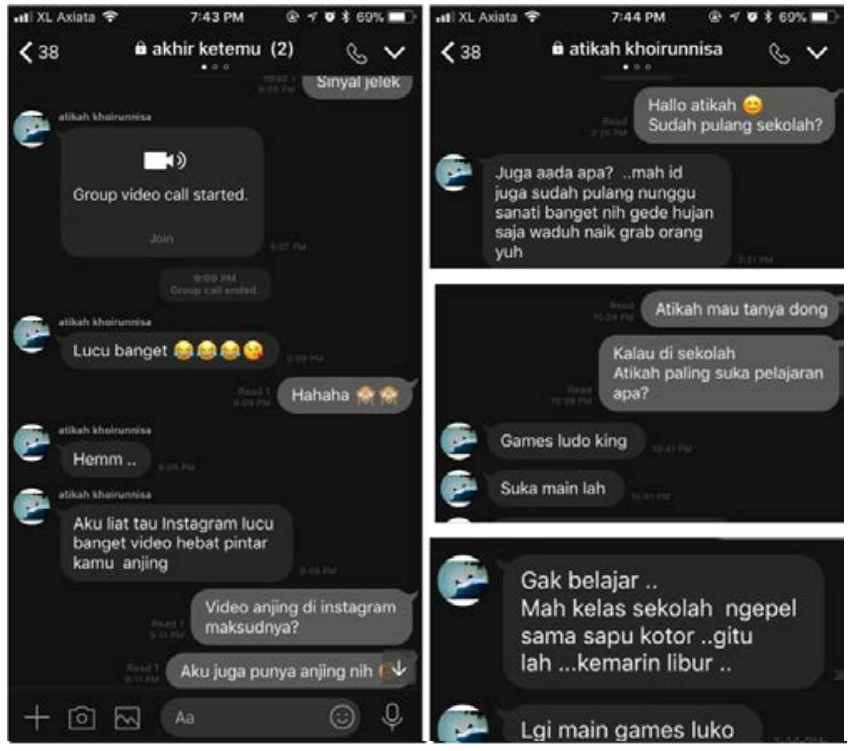

khoirunnisa_tikah Following the right with my friend and love you all 0. \#vscomoscow \#school \#andatheseagiveaway \#goodmorning \#miss 23 APRIL

khoirunnisa_tikah Miss you i'm with friend like and beautiful smile if $\Theta 0$

khoirunnisa_tikah My school and the same as is a good day sir or madam you to do with your time in this case and colleagues who are stuck to\#school2015 \#lebihbaik \#temantemanan \#andyhurley .

khoirunnisa_tikah Murid guru Bu Dista yang lebih baik bermanfaat untuk love you pada tetap semangat dalam anak-anak jadi pintar dan rindu sekali lagi padaku kenangan ingin kangen udah lama saja foto lumanyan tuh ma pindah terus peluk bu dista jangan sedih harus tenang perhatian khusus guru bisa senang dengan juga sedih banget salam buat bu dista 1

Gambar 3. Studi kemampuan Berbahasa Siswi Tunarungu Skh YKDW 02

Sumber : Dokumentasi Pribadi, 2018

Kalimat Atikah: "Aku liat tau instagram lucu banget video hebat pintar kmu anjing. Gak belajar mah disekolah ngepel sama sapu kotor gitu lah kemarin libur”.

Kedua kalimat ini memperlihatkan adanya kesalahan tata bahasa yang cukup banyak sehingga pesan Atikah kurang dapat dipahami oleh lawan bicara

Langkah berikutnya adalah mengadakan FGD Partisipasi 1. Tujuan FGD Partisipasi 1 ini adalah memahami permainan apa yang paling disukai siswi tunarungu YKDW. Peneliti membawa 5 jenis permainan, yaitu: kartu UNO, scrabble, monopoli, catur, dan spin wheel. Sebanyak 11 orang siswi SMP kelas tiga dari dua kelas dikumpulkan dan diminta untuk bermain 5 permainan tersebut. Mereka diminta 
memainkan permainan tersebut masing-masing 10 menit (Gambar 4). Bila siswa belum pernah main maka tidak perlu bermain. Pada akhir sesi setiap permainan, mereka diminta memberikan responnya terhadap rangkaian pertanyaan survei. Seluruh komunikasi dengan mereka dilakukan secara tertulis.

Dari data FGD, dapat disimpulkan bahwa anak penyandang tunarungu lebih sering bermain dengan kartu dan dadu. Permainan yang dimainkan adalah permainan sederhana yang cenderung tidak memerlukan banyak aturan dan strategi. Mereka jarang memainkan permainan yang tidak umum. Data FGD juga menunjukkan bahwa mereka lebih suka memainkan permainan yang memiliki banyak warna.

Dari hasil FGD itu pula, dapat dipahami bahwa karakter permainan yang disukai anak tunarungu adalah permainan yang sederhana dan seru. Data ini digabung dengan hasil studi kurikulum, metode dan sarana belajar bahasa yang ada di sekolah. Kata kunci yang diambil dalam perancangan adalah fun dan edukatif. Selanjutnya, proses perancangan dimulai dari penyusunan konsep, sketsa, pembuatan dummy, tes dummy, pembuatan prototipe, hingga uji coba prototipe. Sebelum mengembangkan ide permainan diputuskan bahwa permainan harus memiliki ketiga elemen utama yaitu: (1) kartu flash SPOK bertema kegiatan praktek: memasak dan menjahit, karena disesuaikan dengan kurikulum Skh YKDW 02 yang memang memfokuskan pada keahlian vokasi. Tujuan dari kartu ini adalah agar kosakata siswi bertambah dan diharapkan siswi dapat menulis dengan jelas di kelas praktik ini. Kartu berfungsi sebagai pedoman dalam membuat kata dan dapat digunakan sebagai kamus juga karena terdiri dari kata, sibi, arti sesuai KBBI; (2) tantangan berbahasa: instruksi untuk membuat kalimat yang disesuaikan dengan pelajaran bahasa, seperti kalimat aktif, pasif, perintah, instruksi, dll; (3) instruksi permainan SIBI: langkah - langkah permainan yang harus dimainkan siswi tunarungu dijelaskan dengan simbol bahasa isyarat.

Objek perancangan adalah permainan edukatif untuk melatih struktur berbahasa Indonesia, terutama saat menyusun kata menjadi sebuah kalimat. Nama permainan ini adalah 'SPORU' yaitu SPOK untuk tunarungu. Sebuah permainan yang memiliki tujuan untuk melatih struktur berbahasa penyandang tunarungu dengan membuat kalimat sesuai dengan instruksi dan kartu kata yang didapat. Pemain adalah penyandang tunarungu usia 12-15 tahun. Permainan ini bertujuan untuk melatih dan mengasah kemampuan penyandang tunarungu usia 12-15 tahun yang masih terbalik-balik dalam menyusun kata menjadi sebuah kalimat.

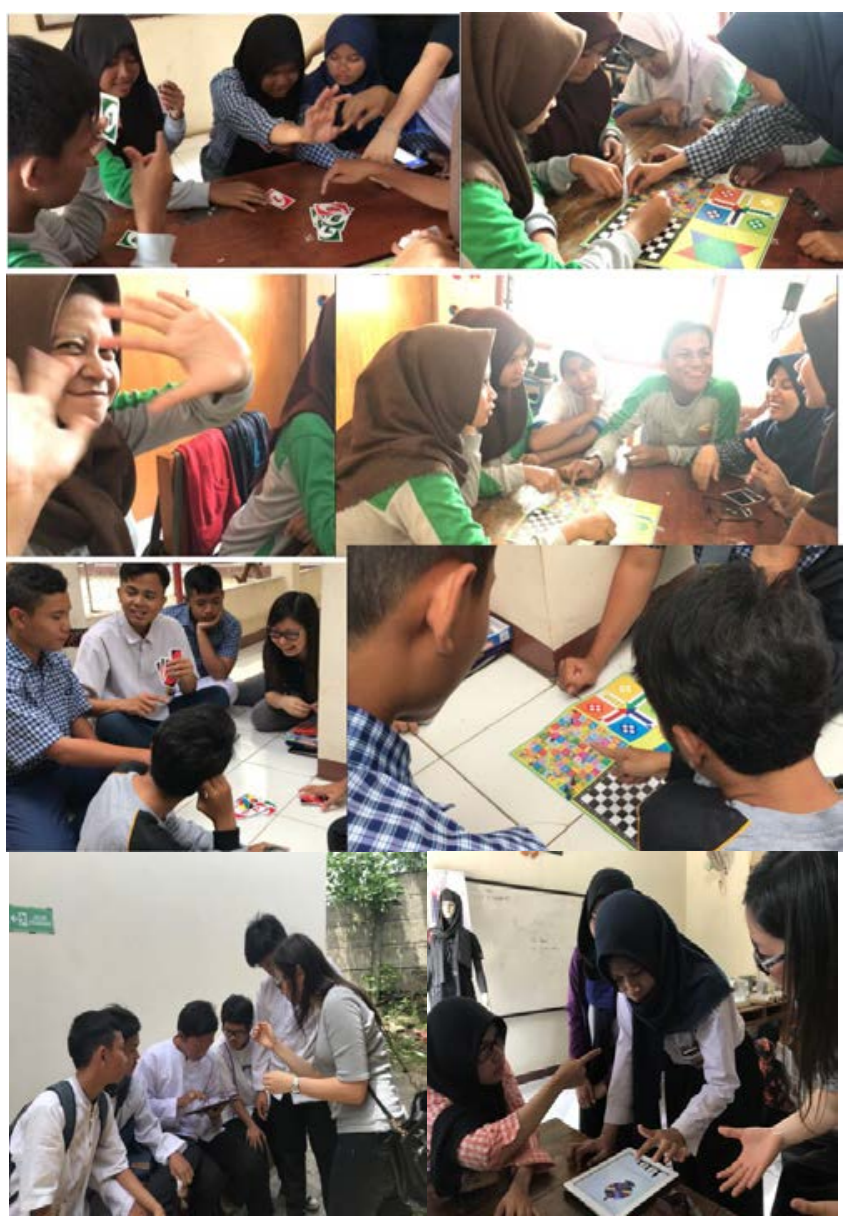

Gambar 4. Partisipasi Focus Group Discussion 1 Sumber: Dokumentasi Pribadi, 2018

Ide permainan dibuat dengan inspirasi permainan yang pernah dimainkan siswi tunarungu YKDW saat FGD partisipasi yang pertama, yaitu : monopoli, kartu uno, serta spin wheel. Beberapa tipe permainan dikembangkan, dan akhirnya dipilih permainan yang diadaptasi dari permainan uno stacko, karena aturan permainan lebih sederhana.

Setelah menentukan alternatif desain terpilih, tim peneliti selanjutnya membuat model dengan skala 1:1 dan diuji coba ke YKDW dalam bentuk FGD yang kedua (Gambar 5). FGD 2 tersebut menghasilkan catatan-catatan yang mengarah kepada penyempurnaan produk. Beberapa di antaranya adalah langkah permainan harus dipermudah, unsur menyenangkannya harus ditingkatkan, tantangan berbahasa harus menyesuaikan dengan konten kekinian. Guru harus menjelaskan lagi apa yang ada di kartu. Khusus untuk anak yang memiliki level intelegensi di bawah rata-rata, penjelasan yang diberikan harus dilakukan berulang-ulang. Anak-anak tunarungu mampu membaca $80 \%$ dari SIBI yang tertera. Guru SKh YKDW mengatakan bahwa anak- 
anak akan kesulitan membaca SIBI yang terlalu banyak. Mereka menyarankan bahwa akan lebih baik, jika hanya intinya saja yang diletakkan ke dalam produk.

Berdasarkan masukan-masukan yang diperoleh dari FGD 2 tersebut, tim peneliti melakukan perbaikanperbaikan desain produk permainan (Gambar 6). Hasil revisi desain langsung diaplikasikan pada prototipe produk. Selanjutnya, produk tersebut diuji coba di SLB Pangudi Luhur dan SKh YKDW 02. Uji coba atau review produk dilakukan dengan cara meminta beberapa responden untuk memainkan produk yang telah dibuat. Delapan orang penyandang tunarungu menjadi responden dalam kegiatan ini. Mereka berusia 14 - 23 tahun (1 SMP dan SMA) dan 3 orang dewasa yang mengajar penyandang tunarungu (Gambar 7). Responden memainkan produk tersebut hingga selesai (balok terjatuh). Hanya saja, sayang sekali review produk tidak dapat dilakukan di SKh YKDW 02 (tempat observasi dan wawancara penelitian difokuskan) karena adanya perbedaan jadwal, di mana ketika review harus dilakukan, anakanak SKh YKDW sedang menjalani Ujian Nasional sehingga sekolah tidak mengizinkan adanya kunjungan pada bulan itu dan setelahnya karena muris SMP kelas 9 libur setelah ujian dan murid kelas $7 \& 8$ sedang persiapan ujian kenaikan kelas. Namun kondisi tersebut tidak menjadi kendala yang berarti dalam penelitian ini.

Di akhir permainan, para responden diminta memberikan penilaian. Skala penilaian berkisar antara skor 1 (tidak setuju/menarik) hingga 5 (sangat setuju/menarik). Lima aspek alat permainan yang direview adalah Balok Tantangan Berbahasa, Flash Card SPOK, Buku Pemain, Kotak Penyimpanan, dan SPORU keseluruhan. Hasil review produk tersebut adalah sebagai berikut: Balok Tantangan Berbahasa memiliki rata-rata total 4.2, Flash Card SPOK (4.2), Buku Pemain (4.2), Kotak Penyimpanan (4.4), dan SPORU keseluruhan (4.0). Rata-rata skor produk yang diberikan responden tersebut seluruhnya di atas 3 (nilai tengah) dan cenderung ke arah 5 (sangat setuju/menarik).

Hasil tersebut menunjukkan bahwa responden menyukai produk tersebut. Bahkan kepala sekolah SLB Pangudi Luhur pun sangat menyukai produk ini, karena produk ini bisa menjadi alternatif pelajaran bahasa, jadi pelajaran lebih menyenangkan (Gambar 8). Hanya saja kurang bisa diterapkan di Pangudi Luhur, karena di Pangudi Luhur tidak mengajarkan bahasa isyarat sama sekali.

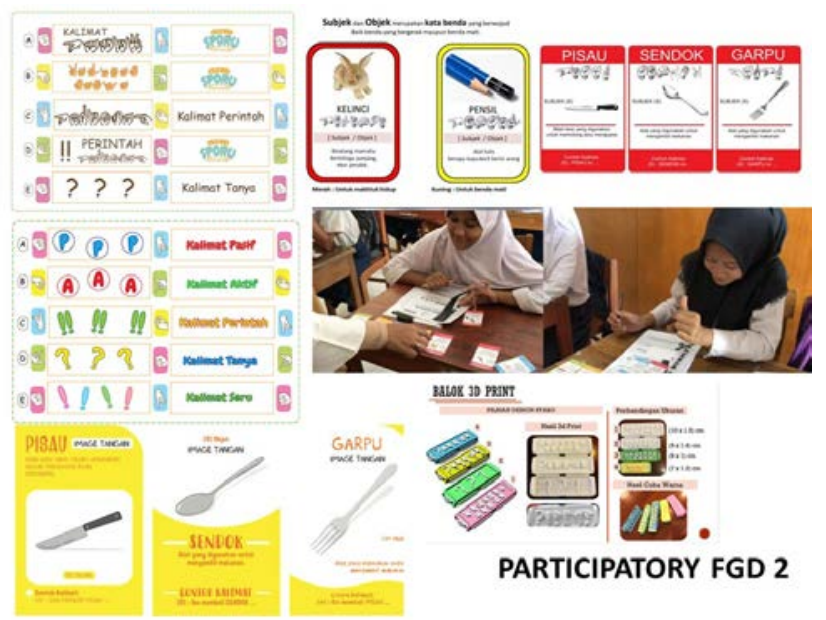

Gambar 5. Focus Group Discussion 2 Sumber: Dokumentasi Pribadi, 2018

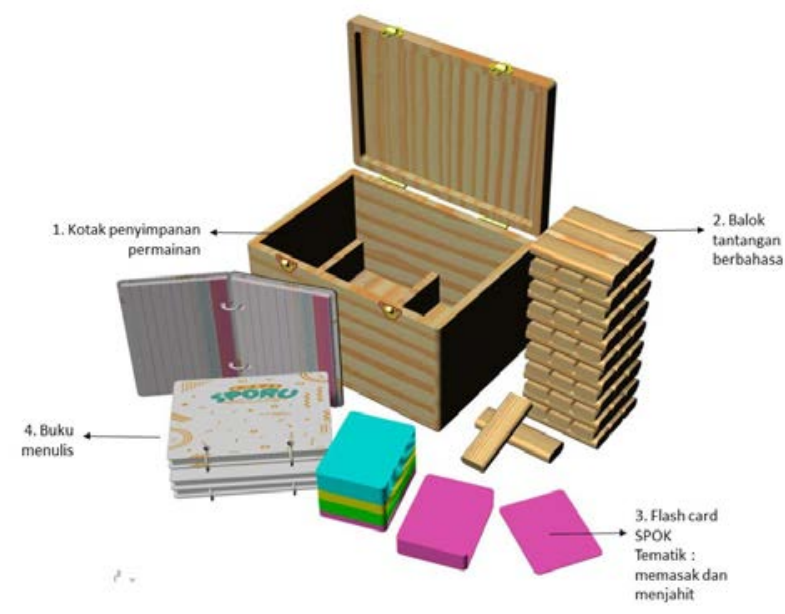

Gambar 6. Desain akhir alat permainan berbahasa siswa tunarungu

Sumber: Data Pribadi, 2018

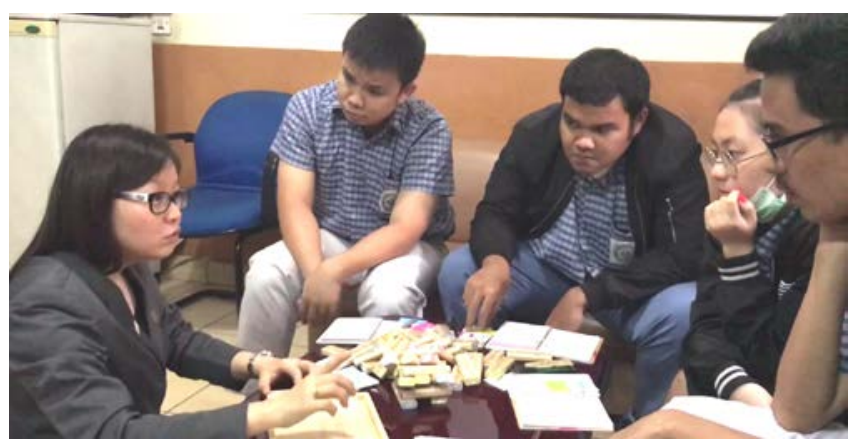

Gambar 7. Review produk alat permainan Sumber: Dokumentasi Pribadi, 2018 


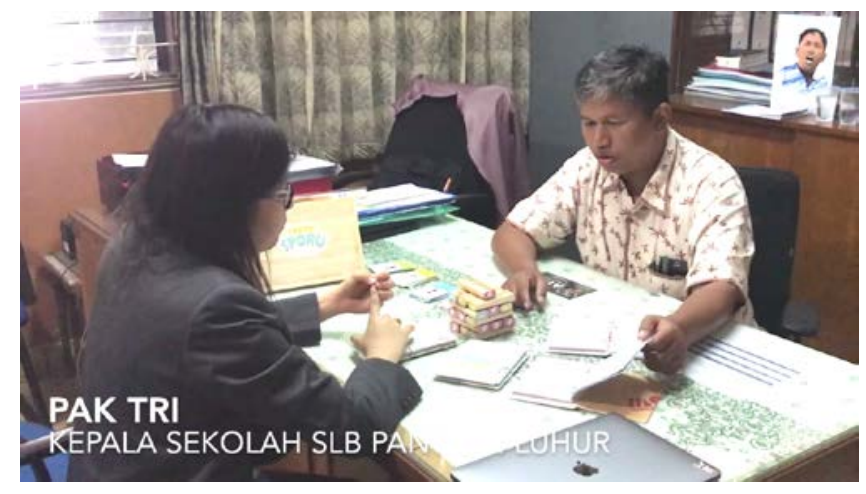

Gambar 8. Review produk alat permainan dari Kepala Sekolah Pangudi Luhur

Sumber: Dokumentasi Pribadi, 2018

Perancangan dengan pendekatan metode participatory ini bertujuan agar desain yang dihasilkan lebih empatik dan tepat sasaran, khususnya bagi siswi tunarungu. Ada beberapa poin yang dapat dicatat dari proses tersebut, yaitu bahwa stakeholder inti dari perancangan ini adalah guru, perancang, dan siswi tunarungu; FGD yang diakhiri dengan pengisian kuesioner dinilai cukup efektif karena data terekam langsung secara elektronik; komunikasi verbal antara peserta FGD dengan perancang yang minim pengetahuan bahasa isyaratnya cukup menyulitkan proses FGD, sehingga diputuskan komunikasi secara tertulis; keterbatasan waktu untuk melaksanakan FGD partisipasi juga menurunkan kualitasnya, karena siswi kelas 3 SMP sudah banyak yang fokus pada kegiatan try out ujian akhir nasional, sehingga guru tidak memberikan waktu yang cukup bagi perancang untuk melakukan proses FGD partisipasi; keberagaman level intelegensi siswi Skh YKDW 02 juga menyulitkan perancang merumuskan aturan permainan yang mudah dipahami tapi masih seru; keberagaman metode: FGD, observasi dan wawancara memperkaya proses perancangan; tema-tema flashcard belum dimasukkan dalam pertanyaan FGD, karena materi terlalu fokus pada pelajaran bahasa sehari-hari.

\section{Kesimpulan}

Setelah melewati penelitian ini disimpulkan bahwa tidak ada standar pendidikan yang sama untuk sekolah tunarungu. Perbandingan antara dua sekolah: SKh YKDW 02 (komunikasi menggunakan bahasa isyarat) dan SLB Pangudi Luhur (komunikasi tidak boleh menggunakan bahasa isyarat) menunjukkan hal itu. Siswi sejak dari awal diajar untuk tidak bersifat eksklusif dan harus bisa berkomunikasi seperti layaknya orang normal. Hal ini sangat dirasakan peneliti dalam proses peneltian ini di mana dengan siswi Skh YKDW 02 lebih pemalu sulit untuk mengutarakan maksud pikirannya, jarang bertatap mata langsung. Siswi Pangudi Luhur lebih terbuka dan ada kontak mata yang baik. Kementerian Pendidikan dan Kebudayaan RI harusnya lebih memperhatikan standar pendidikan sekolah khusus, karena sayang sekali karena keterbatasan ekonomi siswi tidak mendapat standar pendidikan yang sama.

Penelitian dapat dilanjutkan, permainan SPORU diadaptasikan untuk sekolah tunarungu lainnya seperti Pangudi Luhur, karena mereka sendiri merasa kesulitan mencari sarana belajar yang menyenangkan dan edukatif untuk siswi SMP.

\section{Ucapan terima kasih}

Artikel ini merupakan publikasi penelitian internal Universitas Pelita Harapan dengan Nomor P006/I/SOD/2018 dan terdaftar di LPPM UPH. Penulis mengucapkan terima kasih kepada berbagai pihak yang telah membantu dalam penyusunan karya ilmiah ini. Secara khusus, Penulis menyampaikan terima kasih kepada Dr. Martin L. Katoppo S.T, M.T.selaku Dekan Fakultas Desain Universitas Pelita Harapan dan Dr.-Ing. Ihan Martoyo, S.T., M.Sc selaku Ketua LPPM Universitas Pelita Harapan.

\section{Daftar pustaka}

Afandi, M. (2013). Modul Participatory Action Reseacrh (PAR). Modul Participatory Action Reseacrh (PAR). Surabaya: Lembaga Pengabdian Masyarakat IAIN Sunan Ampel.

Baker, B., Dearden, P., \& Thomas, S. (2003). Consultation for a Change (PDF). Conference Proceedings. Wolverhampton: CIDT/RRI/Oxfam/SPA.

BisaMandiri. (2015). Klasifikasi Anak Tunarungu. Retrieved November 6, 2017, r from https://bisamandiri.com/blog/2015/10/klasifikasi-anak-tunarungu/

Elliot, J. (1991). Action research for educational change. Milton Keynes, UK: McGraw-Hill Education.

Involve. (2005). People and Participation. Retrieved November 6, 2017, from https://www.involve.org.uk/resources/publications/practicalguidance/people-and-participation

Isma, S. T. P. (2012). Signing varieties in Jakarta and Yogyakarta: Dialects or separate languages. Tesis. Tidak Diterbitkan. Hongkong: Chinese University of Hong Kong.

Katoppo, M. L. (2018). Desain sebagai generator: bagaimana desain menjadi terang bagi semua orang. In L. P. Santyaputri \& E. Irwandi (Eds.), Prosiding Seminar Nasional: Desain Sosial (Perubahan sosial, desain kolaborasi dan media sosial). 
Tangerang: Fakultas Desain Universitas Pelita Harapan.

McTaggart, R. (1994). Participatory Action Research: issues in theory and practice. Educational Action Research, 2(3), 313337. https://doi.org/10.1080/0965079940020302

Melinda, E. S. (2013). Pembelajaran adaptif bagi anak berkebutuhan khusus. Jakarta: Luxima.

Sadjaah, E. (2005). Pendidikan bahasa bagi anak gangguan pendengaran dalam keluarga. Jakarta: Depdiknas Dirjen Dikti. Stringer, E. T. (2013). Action Research (4th ed.). Thousand Oaks, California: SAGE Publications, Inc.

Yang, C.-F., \& Sung, T.-J. (2016). Service design for sosial innovation through participatory action research. International Journal of Design, 10(1), 21-36. 